\title{
Sustaining Our Oceans: A Public Resource,
}

\section{A Public Trust}

Remarks By

Admiral James D. Watkins, U.S. Navy (Retired)

Chairman, U.S. Commission on Ocean Policy

Before

The National Academies/Ocean Studies Board

Fifth Annual Roger Revelle Commemorative Lecture

November 5, 2003, Washington, D.C.

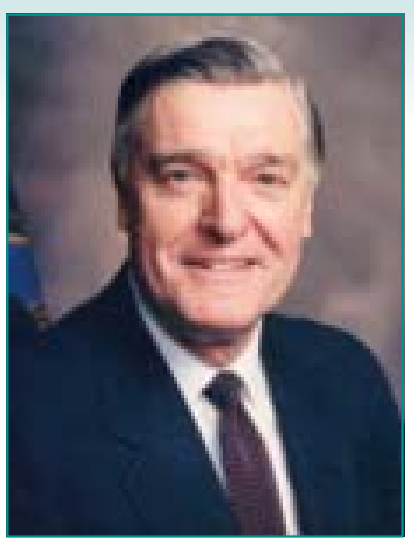

\section{Introductory Remarks}

It's a special honor for me to be with you this evening to present the Fifth Annual Roger Revelle Commemorative Lecture. The highly respected Dr. Revelle made so many significant contributions in oceanography, and his vision for "blue water" research was instrumental in making Scripps the oceanographic powerhouse it is today, including the RV Roger Revelle, a research ship that has taken so many teachers and students out to sea. And, like me, he was an old salt, having served in the Naval Reserve and then in the regular Navy during WWII until 1948 when he returned to Scripps after completing his service as head of the Office of Naval Research's Geophysics Branch. As a submariner and as the Chief of Naval Operations, I fully appreciated, and the Navy benefited from, his unique contributions to advancing our knowledge of the oceans and the seafloor. Roger and his colleagues helped us win the Cold War.

\section{USCOP Update}

Since I know you're all wondering, I'll start with a brief update on where the U.S. Commission on Ocean Policy is in preparing its report for the President and Congress. Dr. Jim Coleman, one of our Commissioners and a member of the Ocean Studies Board, will also give an informal update at tomorrow's Board meeting. We are in the final deliberative stages and are writing the draft report which we will send to the Nation's Governors and make available online for public review as soon as possible. After the Governors and others review it, the Commission will consider their comments and submit the final report to the President and Congress. The process has been long and arduous. We held 15 public meetings, in 9 different regions of the country, went on 17 field trips, and received formal testimony from more than 400 presenters and informal oral and written comments from many others. We are working on the premise that the President and the Congress are serious about the need for generating a national ocean policy that realizes the objectives laid out in Oceans Act 2000, our enabling legislation. We are united in our desire to write the most comprehensive and compelling report possible, one that is taken seriously by the White House, Congress and the broad stakeholder community and which includes recommendations that Congress and the White House will want to implement.

\section{The Importance of Our Oceans and Ocean Resources}

As most of the folks in this audience know, 70 percent of this planet we call "Earth" is actually covered by the oceans. They affect and sustain life and influence the health and well-being of all humankind. They provide us with food, pharmaceuticals and other natural products, transportation corridors, recreational opportunities, and a national security buffer. They drive and moderate weather, climate, and climate change. Likewise, humans influence the well-being of the oceans. Point source and non-point source pollution, over-harvesting of fish and other living resources, habitat destruction, and introduction of non-native species are just some of the ways humans can negatively impact the oceans, and in turn, negatively impact themselves.

Since the publication in 1969 of the Stratton Commission's report, "Our Nation and the Sea," much progress has been made in the way we deal with our ocean resources, but much more progress needs to be made. In the last 30 years, approximately 30 million individuals, 17 million homes, and countless businesses have been added to the coastal zone; offshore oil and gas operations have expanded; the country has become 
more and more dependent on marine transportation; and coastal recreation and tourism have become two of the top drivers of our national economy. However, these developments have also incurred costs, and we are only now discovering how large the debits are in terms of depleted resources, habitat loss, pollution, conflicting laws, etc. Our ability to manage our marine resources is not keeping pace with the pressure society is placing on them.

Continued population growth and increasing human habitation and development in coastal areas are exerting increased pressures on the world's oceans and ocean resources. To balance these pressures intelligently with a sound, scientifically based strategy for protecting and sustaining our oceans requires a coordinated and comprehensive national ocean policy. This national policy must also incorporate principles of international cooperation for ensuring the health and sustainable use of global ocean resources. To accomplish this requires a sea change in the way we manage marine resourcesor rather, the way we manage human activities which affect marine resources.

As the title of my talk states, the oceans are both a public resource and a public trust, and we must develop new science, management and policy tools so that future generations can continue to enjoy and benefit from the oceans as we do.

While there are many areas which require change, I see four as being especially critical if we are to achieve a national ocean policy which is viable, effective, balanced, based on credible science, and adaptable to new information and improved management tools. We need:

- A new model for ocean governance

- Adoption of an ecosystem-based management strategy

- Increased investment in science and technology

- Enhanced ocean education

\section{Ocean Governance}

The U.S. is awash in a sea of disparate, confusing and single-issue governance tools. We need a new mechanism to bring ocean resource management within an integrated structure that treats ocean resources as interrelated and interdependent ecosystem components, not a collection of isolated fragments managed independently from each other as practiced today. This insular and disjointed policy approach of the past has led to confusion and contradiction and will continue to do so until remedied. Further, the Byzantine patchwork of Federal, State, and local authorities that guide ocean policy has been worked into such a knot it is hard to imagine how the system functions at all. We continue to see the weaknesses inherent in such a system. The endless litigation over fisheries and growing confusion over authorities for emerging ocean uses such as wind farms and aquaculture are timely examples.

Witnesses before the Ocean Commission have stressed the need for coordination among the many laws and policies that guide our use and preservation of coastal and ocean resources. Mechanisms to implement such an integrated approach to a new governance structure include:

- basing its structure on ecosystems and using proactive and adaptive management methods;

- developing principles of ocean stewardship and incorporating them into the structure through public-private partnerships;

- integrating the government structure both horizontally and vertically; and

- enabling more consistent participation by regional stakeholders and management experts.

The Commission has heard a clear, clarion call for a new model for ocean governance. As a result, the Ocean Commission is considering a new National Ocean Policy Framework that would initially be created by Presidential Executive Order and then codified by Congress. This Framework would include an Executive Office of Ocean Policy, a National Ocean Council, and a non-Federal Presidential Advisory Committee on Ocean Policy. The Executive Office of Ocean Policy would be headed by an Assistant to the President who would chair a National Ocean Council composed of cabinet secretaries and directors of independent agencies. The Presidential Advisory Committee would consist of non-Federal representatives from State, regional, and tribal governments and other key private sector stakeholders involved in ocean planning functions.

In addition to this national level approach, there is a need for better planning and coordination at regional, State and local levels. Most of the pressing issues of today are regional in scale, and today's "top down" governance system is not designed to successfully transcend jurisdictional lines. The creation of regional ocean councils, non-regulatory in nature and representative of State and local policymakers and other stakeholders, is a potential "bottom-up" mechanism under consideration. These councils could identify and address ocean and coastal issues at the regional level and provide input, as required, to the Federal leadership via the new framework we have designed. This concept is particularly intriguing since regional approaches to ocean issues are better suited to implementation of the ecosystem-based management approach.

\section{Ecosystem-Based Management}

Single issue, single species resource management 
approaches are not adequate to address today's and tomorrow's needs. In the 34 years since the Stratton report, we have learned a tremendous amount about the interactions and interdependencies of species and their responses to environmental conditions. The concept of "food chains" has been replaced by "food webs." Cumulative impacts and synergistic effects of human-caused alterations are now part of the scientific lexicon. Interdisciplinary research is now common and simplistic two-species interaction models have been replaced by dynamic ecosystem models based on causal, rather than empirical, relationships. It is time that our approach to ocean resource management catches up with these advances in scientific knowledge and information technologies.

What do we mean by ecosystembased management? On the surface it sounds simple, and biologists and ecologists have a grasp of what it means. But, to define it in words and then to put it into practice is not a trivial task. The Ocean Commission has grappled with a way to articulate the principle of ecosystem-based management. After much debate, we agreed that:

"U.S. ocean and coastal resources should be managed to reflect the relationships among all ecosystem components, including humans and non-human species and the environments in which they live. Application of ecosystem-based management will require defining geographic management areas based on ecosystem, rather than political, boundaries."

As the nation moves toward ecosystem-based management of ocean and coastal resources, researchers will have to provide the scientific information needed to implement appropriate policies and actions. This will require better communication between scientists and managers and a better translation of research data into understandable and useful information. As one of our Commissioners has repeatedly said, "We don't need more data. We need more information." This translation of data into useful information is a major challenge not being met today.

\section{Science \& Technology}

Gaining a solid scientific understanding of the ocean environment must be made a national priority. Effective science-based measures should be taken immediately to safeguard, protect, and restore our oceans and coasts for the use and benefit of current and future generations. This requires a commitment to support and conduct high-priority research and to build the requisite scientific and technological tools needed to enable policymakers and managers to make sound, science-based decisions to protect our coastal and ocean resources, to protect human lives and property from coastal and ocean hazards, and to guarantee sustainable societal and economic benefits from the oceans.

The nine Federal agencies with major ocean activities currently spend a total of about $\$ 650$ million annually on basic and applied ocean research. This expenditure, when measured in constant dollars, has been stagnant for the past 20 years and is wholly inadequate to meet today's coastal and ocean information needs and to provide the level of information necessary for policymakers and managers to make timely, informed decisions. Federal funding for ocean R\&D has actually decreased from seven percent of total Federal R\&D budget in 1982 to about 3.5 percent today. We need to at least double this investment in ocean R\&D just to bring it back to parity with the 1982 level. And, yet we see the Federal Government dragging its budgetary feet, and in some cases further reducing its investment in ocean science. For example, at the beginning of this year the Board of Governors of the Consortium for Oceanographic Research and Education, known as CORE, sent a letter to the Secretary of the Navy expressing their concern that the Navy was cutting back on long-term, high-risk basic research funding in favor of short-term, product-driven research. That letter makes an excellent case showing how the basic research of 10 , 20 , and 30 years ago led to critical new technologies for the Navy. Recently, the Navy has taken even more devastating cuts from within their long-term 6.1 and 6.2 research accounts. Someone needs to challenge their rationale for this move.

Compounding this dour funding picture is the lack of interagency coordination of existing coastal and ocean programs and the inefficient use of ocean science investments. While some efforts are under way to coordinate the diverse Federal ocean science and technology efforts, for example the National Oceanographic Partnership Program, there is no comprehensive national ocean policy to guide them. Thus, a national strategy for coastal and ocean science and technology must foster and strengthen interagency coordination, define the appropriate roles of government, academia and industry, and ensure that the necessary land-, water-, air-, and space-based infrastructures and resources are in place.

Attendant with this is a further need to develop new strategies and methodologies for the conduct and application of science and technology to address the coastal and ocean challenges of the 21st century. New approaches for observation and integration of ocean, atmosphere, and terrestrial processes should be developed and implemented. 
One fundamental tool on the horizon for advancing our understanding of the marine realm is the Integrated Ocean Observing System. Successful implementation of the IOOS will be a huge advance in our ability to observe, monitor, and forecast ocean conditions. However, there must be a national will to build and sustain the IOOS over time, to integrate it with other air, land, and sea observing systems into a holistic Earth observing system, and to meet the operational and educational requirements of the user community, not just serve as a nifty research tool for the scientific community. We need an ocean observing system that satisfies real world needs, just as the National Weather Service does with its suite of environmental forecasts and warnings. Anything less will not garner the national support necessary to its success and maintenance over time.

With adequate coordination, instrumentation, technology development, and funding, the IOOS will provide significant economic, societal, and environmental benefits to the nation and valuable information for a multitude of diverse users. The annual costs for operating, maintaining, and upgrading the national IOOS is on the order of $\$ 650$ million, including the cost of dedicated satellite observations. This new investment is in addition to the $\$ 650$ million increase for basic ocean research which I mentioned earlier. When the IOOS is seen as part of a larger, fully integrated "Earth observing system," its costs pale in light of what is being spent and what is planned to be spent by the Federal Government for the environmental observing systems currently in place (for example, observations related to weather, hydrology, pollution monitoring, etc.). We have been talking about and planning an ocean observing system for a couple of decades; it is now time to get on with it. It will not "break the bank."

\section{Ocean Education}

As critical as the oceans are to us, the American public has a poor understanding of the role oceans play in their lives and livelihoods and the impacts they themselves have on the oceans. It is imperative that the nation fosters an ocean-literate society that is equipped to deal with existing and impending issues and which is able to make choices and influence decisions based on knowledge. All citizens need a basic understanding of their own interconnection to the marine environment and should feel a sense of ownership and responsibility for that environment. Richard Purdy Wilbur, Poet Laureate of the United States, was right when he wrote, "All that we do is touched with ocean." Reaching a national audience, then, will require coordinated and effective programs to promote and enhance ocean education, both formal and informal.

The Commission believes that there are things that can be done to enhance the public's ocean knowledge. For example:
- Train teachers to teach ocean sciences. The National Science Foundation's Centers for Ocean Science Education Excellence are a good step in this direction. That initiative should be expanded and should involve other Federal ocean agencies.

- Incorporate ocean science into the National Science Education Standards and into classroom curricula. The National Science Education Standards released by the National Research Council in 1996 contain virtually no reference to ocean sciences despite the fact that oceans represent an excellent, motivational opportunity to engage students in all areas of science.

- Foster better cooperation and communication between educators and researchers so that the nation can realize the full potential for integrating research into effective, stimulating and timely educational materials and experiences.

- Capitalize on ocean exploration as an inspirational education tool. The excitement of discovery and exploration can be a potent catalyst to get students interested in science. The new NRC report on Ocean Exploration was publicly released just yesterday with remarks by Congressmen Greenwood and Farr, both staunch supporters of oceans and the U.S. Commission on Ocean Policy. Hopefully this report will draw attention to the need for a vigorous program of ocean exploration; one that will capture the public's imagination and serve as acatalyst for further research.

- Develop a coordinated and effective mechanism to promote and enhance ocean science education in grades $\mathrm{K}-12$ and to link informal education and outreach efforts such as those offered by marine aquaria, zoos and museums.

Ocean education at all levels is the foundation for the future protection and sustainability of our marine resources and for the health and well being of this nation.

\section{The Challenge}

Perhaps the most pressing challenge facing us all is whether there is a strong will, and strong sense of urgency, in Congress, the White House, and among the ocean community and the general public to accept, support, implement and sustain actions and policies needed to resolve the issues we face and grasp new opportunities as they arise. All 16 Commissioners think the will is there. But, to succeed, we're going to need a "full court press" from all ocean stakeholders, a concerted and united call from the public and the 
ocean community for action. The National Research Council is highly respected on Capitol Hill and within the national and international science communities. When the NRC speaks and publishes, people listen and read. Thus, I challenge you and all the other stakeholders to meet this call, to put aside differences and self-serving interests for the common good.

When our report comes out you may not agree with all of our recommendations and you may think that some particular area did not receive adequate treatment. That is understandable and inevitable, but it should not prevent you from supporting the creation of a comprehensive and coordinated national ocean policy. High tides float all boats, and this ocean swell will benefit the nation and everyone in the ocean community. There has been a tremendous national focus on marine issues over the past few years and we must not lose that momentum. This is the first golden opportu- nity we have had since Stratton to really focus national attention on the myriad ocean and coastal issues facing us and to implement a national ocean policy that protects and sustains coastal and ocean resources for the benefit of all. But we are going to need the help of everyone in this room - through your local, county, State, and Federal agency representatives, the Congress, and the business communities to encourage their follow-through and persuasive involvement in the implementation process. This may be the only realistic chance we'll have again for many years.

In closing, let me say that I have enjoyed this opportunity to share my thoughts with you on what I believe are crucial issues facing the nation and the steps we must take to forge a new national ocean policy. I thank the Ocean Studies Board for inviting a nonscientist like me to be this year's Revelle speaker and I would be pleased to take your questions.

\title{
Here's a peek at upcoming issues of Oceanography...
}

17-2 (June 2004)

\author{
Hyperspectral Coastal Ocean Dynamics Experiment (HyCODE) \\ Guest Editor: Joan Cleveland, Office of Naval Research
}

17-3 (September 2004)

Reviews of Topics in Oceanography

Some of the contributors:

David Smith, University of Rhode Island, on deep ocean biosphere

Mike Steele, University of Washington, on Arctic ice ocean modeling

Raffaele Ferrari, Massachusetts Institute of Technology, on mesoscale eddies

Wonn Soh, Japan Marine Science and Technology Center, on long-term sub-bottom measurements

Miquel Canals, University of Barcelona, on suspended plume formation in the Mediterranean

Pat Tester, National Oceanic and Atmospheric Administration, on harmful algae (Pfiesteria)

Christina Ravelo, University of California Santa Cruz, on climate change over the last

5 million years

17-4 (December 2004)

Strata Formation on European Margins:

A Tribute to EC-NA Cooperation on Marine Geology

Guest Editors:

J.P.M. Syvitski, Institute of Arctic and Alpine Research, University of Colorado, Boulder, USA

Phil Weaver, Southampton Oceanography Centre, United Kingdom

Serge Berne, Institut français de recherché pour l'exploitation de la mer, France

Charles Nittrouer, University of Washington, Seattle, USA

Fabio Trincardi, Istituto di Scienze Marine/Consiglio Nazionale delle Ricerche, Italy

Miquel Canals, University of Barcelona, Spain

18-1 (March 2005)

Women in Oceanography

Guest Editor: TBN 